\title{
The Economics of Higher Education in Nepal: Developing a Sustainability Plan
}

\author{
Sanjaya Acharya \\ Saraswati Multiple Campus, Tribhuvan University, Thamel, Kathmandu, Nepal \\ sanjaya.acharya@smc.tu.edu.np, sanjaya.acharya@gmail.com
}

\begin{abstract}
Nepal universities are in a delicate transition now. The enrolment of students is not encouraging; rather it is declining over the years particularly in public universities. Consequently, the outflow of Nepalese students has got momentum over two decades; and nearly a half-million Nepalese students are currently enrolled in foreign universities. The quality education in Nepalese universities is crucial for the return as well as the significant inflow of Nepalese students in the universities of their homeland. However, higher education requires a sustainability plan particularly for the resource generation and promotion of scientific research/publications. Long-term vision, mission, and strategic measures are particularly lacking in Nepal universities. This requires setting objectives and attainable milestones along with specific strategic measures and financial planning that are missing now. The contribution of this paper is twofold. First, it proposes a monitoring framework in the form of a regression model to use as a tool and observe the improvement in higher education in the country. Secondly, it has proposed a typical Sustainability Plan considered appropriate to Nepal; however, it might be equally replicable to other universities of the developing world. Moreover, it has also suggested measures to make such a plan a success.
\end{abstract}

Keywords: Higher education; Sustainability Plan; Enrolment; Universities.

\section{Introduction}

Along with the advent of democracy in $1951 \mathrm{AD}$, a number of public as well as community colleges were opened in Nepal. By 1965, five public colleges enrolled a total of 5,000 students and 51 community colleges associated with 10,000 students. The first university in Nepal, Tribhuvan University (TU), was established in 1958. The year 1971 witnessed the nationalization of all community colleges and they became part of TU. Up to the beginning of the 1980s, Tribhuvan University was the single choice for higher education in Nepal. The need for multiple universities appeared thereafter to address the problem of a highly bureaucratic and centralized system of Tribhuvan University. Universities in Nepal enjoy significant autonomy in their operation. Academic programs of bachelor's degree and above are regarded as higher education in Nepal. The duration of the bachelor's program varies from three to five years whereas the master's level runs for two years. Some universities also run Post-Graduate Diploma programs; the duration of them is not uniform. Currently, associated with 11 universities and six autonomous academies/institutions equivalent to the deemed university, 1425 campuses are in Nepal. These colleges are of three types: constituent, community, and private ones. The latter two are called affiliated campuses. Constituent campuses receive public funding and universities oversee their academic, administrative and financial management. Affiliated campuses do not receive public funding and universities are responsible.

Only for the supervision of their academic programs and examinations, community colleges receive a very small amount of financial support for capital costs from the government through the University Grants Commission (UGC) (World Bank, 2007). About 423,996 students enrolled among 11 universities in Nepal as of 2018, of which 79 percent are in TU. On behalf of the government, the Ministry of Education (MOE) is responsible for the operation of the tertiary education system in Nepal. However, BP Koirala Institute for Health Sciences (BPKIHS), National Academy of Medical Sciences (NAMS), Patan Academy of Health Sciences (PAHS), and Karnali Academy of Health Sciences (KAHS) all report to the Ministry of Health (MOH); the latter makes the fund flow to these health institutions. University Grants Commission (UGC) makes the fund flow as well as the monitoring of higher education provided by the eleven universities in Nepal. In addition to the significant support from the government of Nepal (GoN), the UGC has also received financial and technical assistance from the World Bank. It is going to accomplish the current phase (2015-2020) of the support by June 2020. The Higher Education Reform Project (HERP) under the financial support from the World Bank is crucial in the transformation of Nepal universities. Despite the constant support from the national government and multilateral development institutions, the quality of Nepalese higher education is not 
improving as expected. This paper is an attempt to develop a scenario of how the support should look like from 2020 onward.

More specifically for the period 2020-2025 to make Nepalese higher education competitive in the global market and supportive to fulfill the domestic requirement as well, educational planning deem necessary. In the backdrop of this situation, the objectives of this paper are two-fold. First, it makes an intensive review of the existing scenario of higher education in Nepal including both teaching and research components followed by its human resources and organizational structures. Secondly, it proposes a sustainability plan for the coming five years that will be a workable and productive one. Third, the paper proposes some strategic measures for immediate action that will be crucial to Nepal's higher education reform. To attain the objectives of the paper, the rest of the paper is organized as follows. Section 2 reviews the current scenario of the higher education system in Nepal including the fund flow mechanism through the University Grants Commission (UGC). Section 3 proposes a Sustainability Plan for the reform of Nepal's higher education. The paper concludes and recommends some strategic measures for immediate action in Section 4.

\section{The Current Scenario}

The higher education theories and models draw applications of theories in economics, sociology, humanity, anthropology, political science, psychology and several other disciplines (Toutkoushian \& Paulsen, 2016). However, our concern here is to have some glimpse from a more economic perspective. We study the level of human resources in Nepalese universities, the financial and human resource management, and the long-term planning of Nepalese higher education. More specifically, we focus on the demand and supply responses of the higher education system with reference to the country scenario of Nepal, the comparative static approach in understanding its dynamics, and the pathway for its reform. In Nepal, higher education refers to the academic programs beyond 12 years of education. Previously, $11^{\text {th }}$ and $12^{\text {th }}$-grade education programs were also in the university and were parts of higher education. However, these two grades are now shifted to higher secondary level. Now university-level higher education, therefore, includes undergraduate programs, master's programs, post-graduate diploma programs, MPhil and Ph.D. research. At present, altogether eleven universities exist in Nepal; they are Tribhuvan University (TU), Nepal Sanskrit University (NSU), Kathmandu University (KU), Pokhara University (PokU), Purvanchal University (PU), Lumbini Buddha University (LBU).

Far Western University (FWU), Mid-Western University (MWU), Agriculture and Forest University (AFU), Nepal Open University (NOU), and Rajarshi Janak University (RJU) are regional universities. Moreover, four autonomous academic institutions are also providing higher education in Nepal - National Academy of Medical Sciences (NAMS), BP Koirala Institute of Health Sciences (BPKIHS), Patan Academy of Health Sciences (PAHS) and Karnali Academy of Health Sciences (KAHS). Nepal Open University (NOU) and RJU (Rajarshi Janak University) are two newly opened universities. As mentioned earlier, Nepal universities have two types of campuses: constituent campuses - campuses directly managed including financial management by the concerned university; and affiliated campuses -whose academic programs are affiliated to a particular university. However, in the case of the latter, the administration and financial management are either by private individuals/organizations (private campuses) or by local community stakeholders (community campuses). The academic activities of both types of campuses are governed by the rules and regulations of the concerned university. There were all together, 1425 campuses in the year 2017/18 (137 constituent, 508 community, and 780 private campuses) with 423,996 students enrolled in different academic programs in higher education. Likewise, 9269 faculty members are working in eleven different universities.

The campuses follow the courses designed by the affiliated universities and examinations are conducted and processed by the Office of the Controller of Examination (OCE) of the respective university. The academic calendar for student enrolment, schedule of exam, the publication of results, courses offered and class hours may vary from one to another university. The sustainability plan requires contributing to attaining Sustainable Development Goals of the United Nations to be attained by the year 2030. More specifically, no geographic, ethnic, and gender discrimination to all levels of education has been envisaged. The institutions of higher education are at present providing courses on science and technology, education, management, social sciences and humanities, law, engineering, forestry, medicine, agriculture and animal sciences, Ayurveda and Sanskrit. They run their academic programs with annual or semester systems at the bachelor, master, M. Phil., 
and Ph.D. levels; but some universities also offer programs such as post-graduate diploma (PGD). Depending upon the stream and subject, bachelor level programs are of three to five years duration; whereas master level programs of two years, and PGD and M. Phil. courses generally of $1 \frac{1}{2}$ years (UGC, 2017, p. 45). Student number in Nepal universities has marginally grown during 2010/11 - 2017/18, by 16,062 (3.94\%) (Table 1 and 2).

Table 1: Student Enrolment in Nepal Universities in Academic Year (A.Y.) 2010/11

\begin{tabular}{|c|c|c|c|c|c|c|c|c|}
\hline University & $\begin{array}{c}\text { HE } \\
\text { Enrolment }\end{array}$ & $\begin{array}{c}\text { Share in } \\
\text { HE Enrolment, \% }\end{array}$ & $\underset{\text { Enrolment }}{\text { PQ }}$ & $\begin{array}{l}\text { Share in PCL] } \\
\text { Enrolment, \% }\end{array}$ & $\begin{array}{c}\text { Others } \\
\text { Enrolment }\end{array}$ & $\begin{array}{l}\text { Share in 0thers } \\
\text { Enrolment, \% }\end{array}$ & Total Enrolment & $\begin{array}{c}\text { Share in } \\
\text { Total Enrolment, \% }\end{array}$ \\
\hline BPKIHS & 1,072 & 0.3 & 120 & 0.6 & 0 & 0.0 & 1,192 & 0.3 \\
\hline $\mathrm{KU}$ & 9,658 & 2.4 & 79 & 0.4 & 0 & 0.0 & 9,737 & 2.3 \\
\hline LBU & 33 & 0.0 & 0 & 0.0 & 0 & 0.0 & 33 & 0.0 \\
\hline NAMS & 203 & 0.0 & 0 & 0.0 & 0 & 0.0 & 203 & 0.0 \\
\hline NSU & 1,798 & 0.4 & 1345 & 7.1 & 802 & 17.4 & 3,945 & 0.9 \\
\hline PAHS & 60 & 0.0 & 0 & 0.0 & 0 & 0.0 & 60 & 0.0 \\
\hline PokU & 16,666 & 4.1 & 0 & 0.0 & 0 & 0.0 & 16,666 & 3.9 \\
\hline PU & 24,726 & 6.1 & 0 & 0.0 & 0 & 0.0 & 24,726 & 5.7 \\
\hline TU & 353,718 & 86.7 & 17485 & 91.9 & 3,804 & 82.6 & 375,007 & 86.9 \\
\hline Total & 407,934 & 100 & 19029 & 100.0 & 4606 & 100.0 & 431,569 & 100.0 \\
\hline
\end{tabular}

Source: (UGC, 2012).

Note: The proficiency certificate level (PCL) phased-out from the university level after 2010/11 and was shifted to higher secondary school level; therefore, only the first column from Table 1 is comparable to the total enrolment as presented in Table 2. A.Y. is for Academic Year.

Table 2: Student Enrolment in Nepal Universities in A.Y. 2017/18

\begin{tabular}{|l|r|r|r|r|}
\hline \multicolumn{1}{|c|}{ University } & Male & & Total & \\
\hline AFU & 1,357 & 621 & 1,978 & 0.47 \\
BPKIHS & 183 & 178 & 361 & 0.09 \\
FWU & 1,840 & 1,846 & 3,686 & 0.87 \\
KAHS & - & 30 & 30 & 0.01 \\
KU & 9,554 & 8,388 & 17,942 & 4.23 \\
LBU & 496 & 209 & 705 & 0.17 \\
MWU & 1,907 & 1,317 & 3,224 & 0.76 \\
NAMS & 130 & 311 & 441 & 0.10 \\
NOU & 519 & 74 & 593 & 0.14 \\
NSU & 3,136 & 606 & 3,742 & 0.88 \\
PAHS & 195 & 345 & 540 & 0.13 \\
PokU & 17,134 & 12,285 & 29,419 & 6.94 \\
PU & 12,826 & 13,302 & 26,128 & 6.16 \\
RJU & 34 & 47 & 81 & 0.02 \\
TU & 151,704 & 183,422 & 335,126 & \\
Total & 201,015 & 222,981 & 423,996 & \\
\hline
\end{tabular}

Source: (UGC, 2017). 
Even the marginal growth of the number of enrolment in Nepal universities is attributed to the undergraduate programs (Table 3 and 4). In post-graduate programs, however, the number of students has declined during 2010/11 - 2017/18. During this period, the number of post-graduate students has declined by $16,899(22 \%)$.

Table 3: Student Enrolment in Different Level of Study/Research Programs in A.Y. 2010/11

\begin{tabular}{|c|c|c|c|c|c|c|c|c|c|c|c|c|c|c|c|c|c|c|c|c|}
\hline \multirow{3}{*}{ Level } & \multicolumn{20}{|c|}{ University } \\
\hline & \multicolumn{2}{|c|}{ BPNAHS } & \multicolumn{2}{|c|}{$\mathrm{KU}$} & \multicolumn{2}{|c|}{ LBU } & \multicolumn{2}{|c|}{ NAMS } & \multicolumn{2}{|c|}{ NSU } & \multicolumn{2}{|c|}{ PAHS } & \multicolumn{2}{|c|}{ PokU } & \multicolumn{2}{|c|}{ PU } & \multicolumn{2}{|c|}{ TU } & \multicolumn{2}{|c|}{ Total } \\
\hline & $\mathbf{F}$ & Total & $\mathbf{F}$ & Total & $\mathbf{F}$ & Total & $\mathbf{F}$ & Total & $\mathbf{F}$ & Total & F 1 & Total & $\mathbf{F}$ & Total & $\mathbf{F}$ & Total & $\mathbf{F}$ & Total & $\mathbf{F}$ & Total \\
\hline Bachelor & 321 & 821 & 3,505 & 8,001 & 0 & 0 & 35 & 35 & 251 & 1,389 & 18 & 60 & 4,871 & 14,996 & 8,950 & 21,556 & 128,591 & 284,910 & 146,542 & 331,768 \\
\hline M.Phil. & 0 & 0 & 27 & 187 & 0 & 0 & 0 & 0 & 0 & 0 & 0 & 0 & 11 & 81 & 0 & 0 & 127 & 237 & 165 & 505 \\
\hline Master & 123 & 251 & 525 & 1,330 & 0 & 0 & 59 & 168 & 17 & 286 & 0 & 0 & 532 & 1,559 & 802 & 3,149 & 21,512 & 68,291 & 23,570 & 75,034 \\
\hline$P G D$ & 0 & 0 & 37 & 57 & 0 & 0 & 0 & 0 & 0 & 0 & 0 & 0 & 15 & 30 & 4 & 21 & 4 & 11 & 60 & 119 \\
\hline Ph.D. & 0 & 0 & 10 & 83 & 1 & 33 & 0 & 0 & 10 & 123 & 0 & 0 & 0 & 0 & 0 & 0 & 37 & 269 & 58 & 508 \\
\hline Total & 444 & 1,072 & 4,104 & 9,658 & 1 & 33 & 94 & 203 & 278 & 1,798 & 18 & 605 & 5,429 & 16,666 & 9,756 & 24,726 & 150,271 & 353,718 & 170,395 & 407,934 \\
\hline
\end{tabular}

Source: (UGC, 2012).

Table 4: Student Enrolment in Different Level of Study/Research Programs in A.Y. 2017/18

\begin{tabular}{|l|r|r|r|r|}
\hline \multicolumn{1}{|c|}{ Level } & Male & Female & Number of Students & Share \\
\hline Bachelor & 168,857 & 195,872 & 364,729 & 86.02 \\
PGD & 43 & 98 & 141 & 0.03 \\
Master & 29,773 & 26,531 & 56,304 & 13.28 \\
M. Phil & 758 & 158 & 916 & 0.22 \\
PhD & 1,584 & 322 & 1,906 & 0.45 \\
Total & 201,015 & $\mathbf{2 2 2 , 9 8 1}$ & $\mathbf{4 2 3 , 9 9 6}$ & 100 \\
\hline
\end{tabular}

Source: (UGC, 2017).

Not only the number of students, but the number of teachers also declined in Nepal universities. During the period between academic years $2010 / 11$ to $2017 / 18$, the number of teachers has declined by 39.6 percent (Table 5 and 6).

Table 5: Number of Teachers in Different Universities in A.Y. 2010/11

\begin{tabular}{|c|c|c|c|c|c|c|c|c|c|c|c|c|c|}
\hline \multirow[t]{2}{*}{ University } & \multirow[t]{2}{*}{$\begin{array}{l}\text { Campus } \\
\text { Type }\end{array}$} & \multicolumn{2}{|c|}{ Professors } & \multicolumn{2}{|c|}{$\begin{array}{l}\text { Readers/Associ } \\
\text { ate Professors }\end{array}$} & \multicolumn{2}{|c|}{ Lecturer } & \multicolumn{2}{|c|}{$\begin{array}{l}\text { Assistant } \\
\text { Lecturers }\end{array}$} & \multicolumn{2}{|c|}{$\begin{array}{l}\text { Others(Induding } \\
\text { Instructors) }\end{array}$} & \multicolumn{2}{|c|}{ Total } \\
\hline & & Female & Total & Female & Total & Female & Total & Female & Total & Female & Total & Female & Total \\
\hline BPKIHS & Const. & na & 52 & na & 26 & na & 66 & na & na & na & 39 & na & 183 \\
\hline $\mathrm{KU}$ & Const. & na & 33 & na & na & na & 171 & na & na & na & 137 & na & 341 \\
\hline NAMS & Const. & na & 43 & na & 35 & na & 42 & na & na & na & 22 & na & 142 \\
\hline NSU & Const. & na & 65 & 3 & 130 & 39 & 520 & 0 & 15 & 0 & 40 & 42 & 770 \\
\hline PAHS & Const. & na & 17 & 0 & 21 & 0 & 47 & 0 & 0 & 0 & 0 & na & 85 \\
\hline PokU & Const. & na & 5 & 0 & 8 & 0 & 64 & 0 & 31 & 0 & 8 & na & 116 \\
\hline PU & Const. & na & na & 0 & na & 0 & 31 & 0 & 4 & 0 & 14 & na & 49 \\
\hline \multirow{3}{*}{ TU } & Total & 48 & 589 & 405 & 2,082 & 423 & 5,242 & 12 & 3,326 & 392 & 2,440 & 1,280 & 13,679 \\
\hline & Comm. & na & 119 & 0 & 210 & 0 & 2,748 & 0 & 3,219 & 0 & 176 & na & 6,472 \\
\hline & Const. & 48 & 470 & 405 & 1,872 & 423 & 2,494 & 12 & 107 & 392 & 2,264 & 1,280 & 7,207 \\
\hline Grand Total & & 48 & 804 & 408 & 2,302 & 462 & 6,183 & 12 & 3,376 & 392 & 2,700 & 1,322 & 15,365 \\
\hline
\end{tabular}

Source: (UGC, 2012). 
Table 6: Number of Teachers in Different Universities in A.Y. 2017/18

\begin{tabular}{|c|c|c|c|c|c|c|c|}
\hline University & Professor & Reader & Assistant Prof & Lecturer & Asst. Lecture & Teaching assistant & Total \\
\hline AFU & 33 & 32 & na & 57 & na & na & 122 \\
\hline FWU & 9 & 11 & na & 71 & 18 & na & 109 \\
\hline PU & 0 & 11 & na & 35 & 13 & 15 & 74 \\
\hline KU & 29 & 52 & 110 & 166 & na & 31 & 388 \\
\hline LBU & 3 & 2 & na & 8 & 10 & na & 23 \\
\hline PokU & 5 & 8 & na & 120 & na & na & 133 \\
\hline TU & 688 & 1990 & na & 3853 & 1061 & na & 7592 \\
\hline MWU & na & 4 & na & 124 & na & na & 128 \\
\hline NSU & 38 & 114 & na & 299 & 33 & na & 484 \\
\hline PAHS & 27 & 22 & 53 & 95 & 19 & na & 216 \\
\hline Total & 832 & 2246 & 163 & 4828 & 1154 & 46 & 9269 \\
\hline
\end{tabular}

Source: (UGC, 2017).

The overall trend in Nepal universities as shown by tables from 1 to 6 reveals that the number of teachers and post-graduate students is declining over the past several years. Up to the undergraduate level, the number of students is marginally growing. The student-teacher ratio is also declining overall; however, it has a varying trend across universities. In Tribhuvan University and BP Koirala Institute for Health Sciences, it has declined; however, in the case of others the ratio has increased (Table 7 and 8).

Table 7: Student-Teacher Ratio in 2010/11

\begin{tabular}{|lcc|}
\hline University & $\begin{array}{l}\text { Student - Teacher } \\
\text { (Including Instructors) }\end{array}$ & $\begin{array}{l}\text { Student - Teacher } \\
\text { (without Instructors) }\end{array}$ \\
\hline BPKIHS - Constituent campuses & 7 & 8 \\
\hline KU- Constituent campuses & 11 & 18 \\
NAMS- Constituent campuses & 1 & 2 \\
NSU- Constituent campuses & 3 & 4 \\
PAHS- Constituent campuses & 1 & 11 \\
\hline PokU- Constituent campuses & 10 & 25 \\
PU- Constituent campuses & 18 & 31 \\
\hline TU- Constituent campuses & 22 & 26 \\
\hline All- Constituent campuses & 19 & 11 \\
\hline
\end{tabular}

Source: (UGC, 2012).

Table 8: Student-Teacher Ratio in 2017/18

\begin{tabular}{|c|c|c|c|c|c|c|c|c|c|c|c|c|c|c|c|}
\hline University & KAHS & MWU & PAHS & FWU & BPKIHS & AFU & NAMS & NOU & RU & NSU & LBU & KU & PU & PokU & TU \\
\hline dents & 30.0 & 3,224 & 540 & 3,686 & 361 & 1,978 & 441 & 593 & 81 & 3,190 & 192 & 7,806 & 2,607 & 2,080 & 110,615 \\
\hline \multirow[t]{2}{*}{ Teachers } & na & 128 & 216 & 109 & 208 & 122 & 205 & na & na & 484 & 23 & 388 & 74 & 133 & 7,592 \\
\hline & na & 25.2 & 2.5 & 33.8 & 1.7 & 16.2 & 2.2 & na & na & 6.6 & 8.3 & 20.1 & 35.2 & 15.6 & 14.6 \\
\hline
\end{tabular}


The student enrolment, students in post-graduate studies, number of teachers, the student-teacher ratio are the basic indicators to signal where the Nepal universities are heading to. We draw some problems in Section 5 and recommend some strategic measures for the proposed action plan to address them.

\section{Methods: Developing a Sustainability Plan}

Formulation of the sustainability plan in higher education is crucial in many countries. In the Canadian system, campus-level sustainability plans exist within the broader country-level educational plan (Lidstone, Wright, \& Sherren, 2015). Based upon the review of major indicators pertinent to the higher education system, this study considers the importance of two major elements is the reform of higher education to be captured in Sustainability Plan: Mission, Values, and Goals set for a planning period, and the development of an index for monitoring the progress over time. Section 3.2 proposes the mission, vision, and values that Nepal universities should follow in the next phase of their higher education reform. This paper proposes a model to measure the scale of educational reform and the relative strength of different variables in this regard. This is explained with the help of the following equation:

$$
U I I_{u}=\beta_{0}+\beta_{1} E U_{u}+\beta_{2} \sum_{r=1}^{4} E G_{u i}+\beta_{3} S T R U_{u}+\beta_{4} \sum_{i+1}^{4} S T R G_{u}+\beta_{5} G P S_{u}+\beta_{6} G P F_{u}+\mu_{u}
$$

Where, u refers to university $\beta_{0}, \beta_{1}, \beta_{2}, \beta_{3}, \beta_{4}, \beta_{5}$ and $\beta_{6}$ are the coefficients of regression. UII refers university improvement index. EU and EG mean enrolment rates in undergraduate and graduate programs, respectively. STRU and STRG are student-teacher ratios in undergraduate and graduate programs, respectively. GPS and GPF mean grants per student and grants per faculty members, respectively.

It includes the graduate programs: bachelors, masters, Ph.D., and post-doctoral; therefore, it ranges from 1 to 4. $\mu$ is the error term. $\beta_{1}, \beta_{2}, \beta_{3}, \beta_{5}$ and $\beta_{6}$ are expected to bear positive relation with EII because they are supposed to contribute to university ranking positively; whereas $\beta_{5}$ is expected to bear negative relation with UII. It is because when the student-teacher ratio is low in higher education, student-teacher collaborative research might be more productive because of frequent interaction. However, the opposite is true in the case of the undergraduate scheme where a higher student-teacher ratio signals a bigger university with more attraction of students. The variable EII requires interpretation. This is the ratio of the number of universities in the world ranking to the rank number of the university under consideration. Therefore, the lowest ranking university has an EII value of 1 and the highest rank university has an index equal to the number of universities included in the ranking. Implementation of this model requires systematic time-series data that lacks in the case of Nepal universities. Therefore, we use some basic indicators in Section 3 to see the performance of Nepal universities and assess the trend of higher education in Nepal. However, the development of a proper database is warranted to see the improvement of higher education over time in line with the variables included in the model presented above.

Mission, Values and Goals: University Grants Commission (UGC) needs to prepare the action plan for the next phase of higher education reform. This paper has proposed a five-year Sustainability Plan (2020-2025) with a clear mission, values, and goals. Furthermore, this should follow some strategic approaches to progress towards attaining its mission and goals. This section presents a model with some insights into this endeavor. The mission of the sustainability plan should be to "strengthen market relevance and quality education, boost collaborative research and innovation, and enhance equitable access to underprivileged groups." Nepalese economy is intended to follow socialistic orientation as guided by the constitution; therefore, an inclusive approach of education in every sector of the country is the part and parcel of the overall development trajectory of the country. Higher education is also not an exception in this regard. The values behind it should be meant as the education for all.

Institutional Reform of UGC: University Grants Commission (UGC) is the channeling source of the public sector funds to provide Nepal universities. UGC primarily receives funds from the Ministry of Education on behalf of the government and distributes them to 11 different universities; however, four autonomous medical academies receive grants from the Ministry of Education via the Ministry of Population and Health. The cleaning and security services should be contracted with professional and private support companies. 
Universities have constituent campuses and affiliated campuses; both of them receive grants from the respective university.

Figure 1: Organogram of the Fund Flow Mechanism through UGC

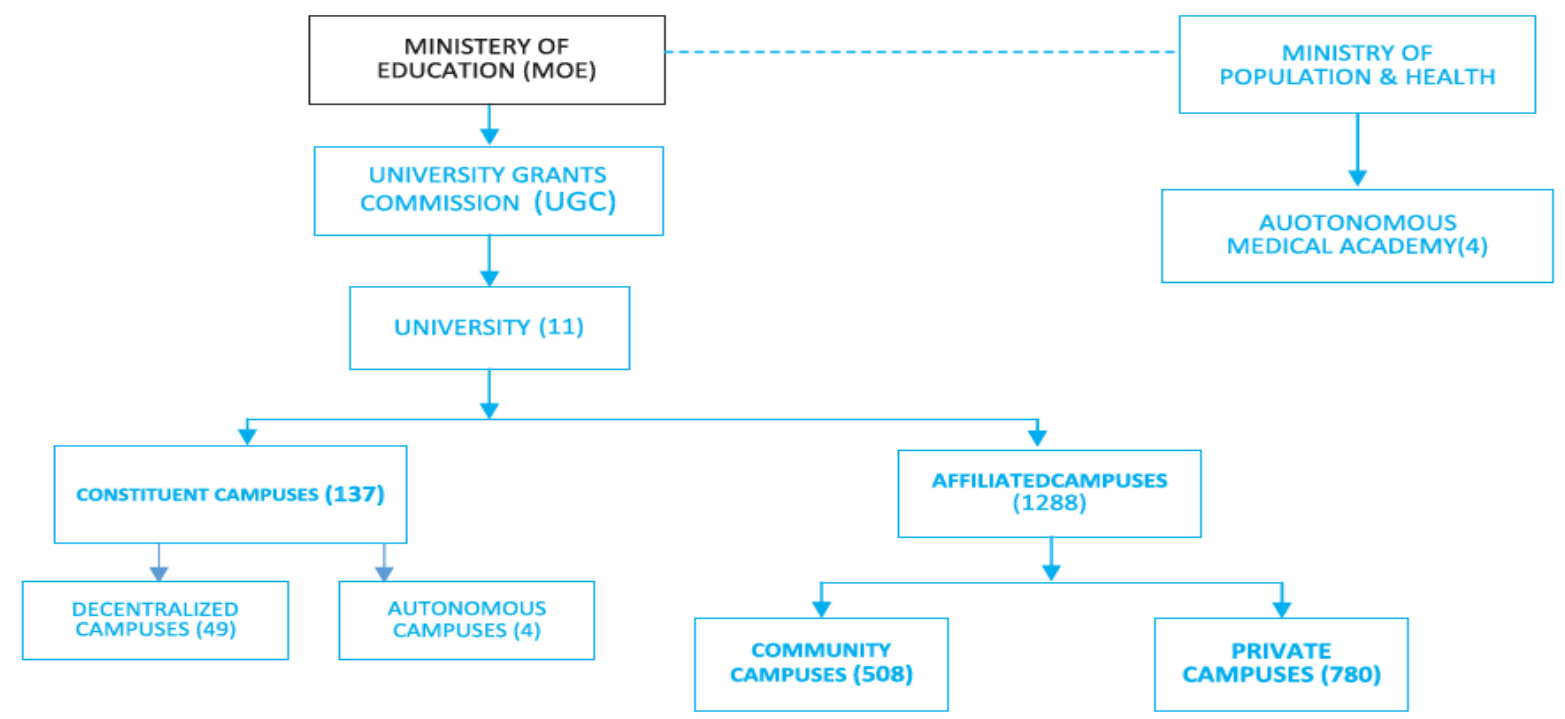

Source: (UGC, 2019, p. 46).

A sustainability plan requires addressing organizational change for sustainability reporting, (Ceulemans, 2015). This is a global practice. Here we discuss whether we need to have changes in the organizational structure of UGC in this regard.

Leadership and Management: UGC has a Chairman and Project Steering Committee; they are supported by Research Council, QAA (Quality Assurance Agreement) Committee, and other committees/sub-committees. Member secretary makes co-ordination of them. These councils, committees, and sub-committees have six different divisions: Administration, Financial Administration, Monitoring and Evaluation, Planning and Program, Research, and QAA. The organogram of the UGC is as shown in Figure 2.

Figure 2: Organogram of UGC

Organizational Chart of University Grants Commission (UGC)

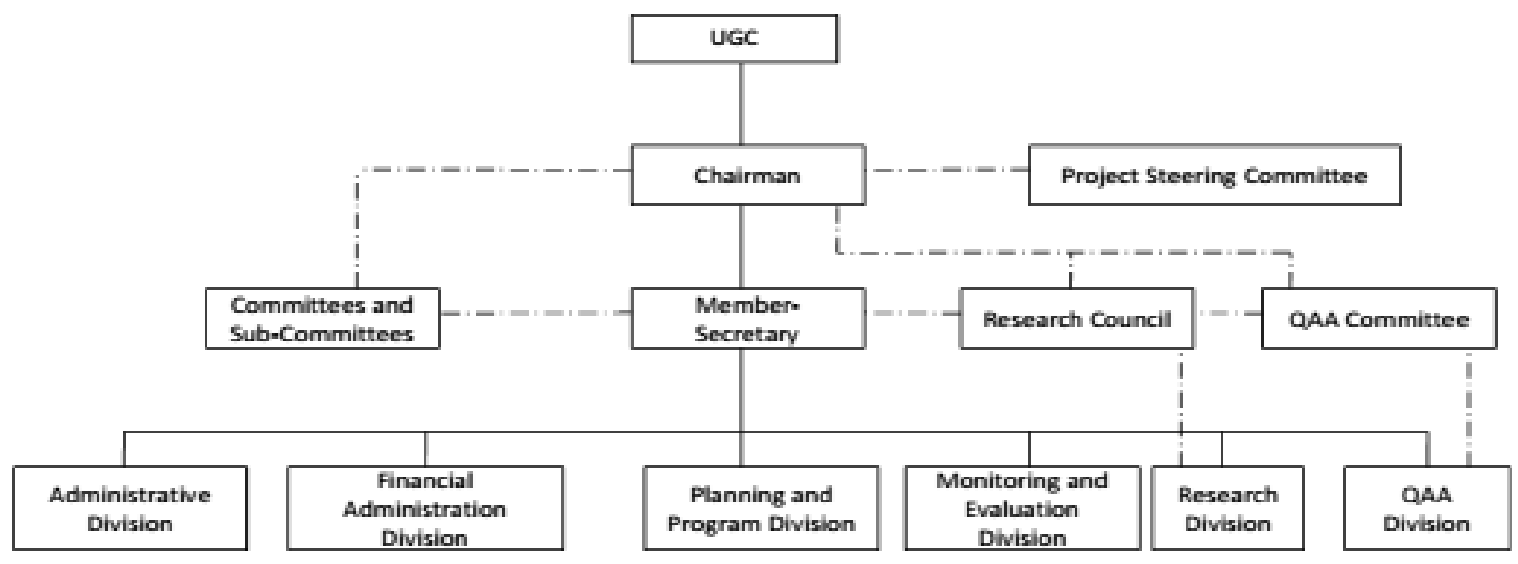

Source: UGC, Research Division. 
The leadership and management structure of UGC looks to have all constituents in the system. This is suggested to remain the same in the next phase of the sustainability plan $(2020-2025)$ as well.

Staffing: The commission had the provision of 31 regular staff; 16 of them are administrative staff and 15 technical/professional staff. All these positions have been fulfilled now. However, the commission has yet to recruit two-second class officer level staff; these two officer positions were created in the year 2096/97 but they still remain vacant. Human resource management should not only follow the plan but also the planning. The number of professional and technical staff requires an increase in the next sustainability plan whereas the number of administrative staff, particularly the office assistants should decline. The cleaning and security services should be contracted with professional and private support companies. A system should be developed to take contractual services from the service provider companies rather than recruiting individual staff for security service, maintenance of office equipment, gardening, cleaning, etc. This not only improves professionalism in the work environment but also reduces the long-term financial responsibility of the institution.

Roles and Responsibilities: Research Division, and Monitoring and Evaluation Division of UGC require strengthening with additional manpower. The Planning and Program Division may also require more senior level professional staff but this division's deliverables can also be enhanced by the intermittent involvement of the experts who can be recruited by out-sourcing. The monitoring and Evaluation Division is expected to establish regular monitoring and evaluation system in UGC and will work as a focal point to coordinate with the constituent and affiliated campuses. This will develop a systematic database of the campuses regarding the physical as well as human resources. A task force formed by the Ministry of Education (MOE) in the year 2012/13 recommended a total of 42 staff in the UGC, including both administrative and technical streams. Currently, UGC contains altogether 31 staff even after eight years. The relevance of the remaining 11 positions (proposed) needs to get reviewed. Upon necessity of them, the recruitment process should be initiated as soon as possible. For the proposed positions, the task force recommending different positions should also provide the job description as well; see also (MOE, 2012).

Systems, Process, Procedures of Fund Flow: KU, PokU, PU do have a relatively large number of students and faculty members next to TU. Therefore, they should have a formula-based grant flow system in place of the current traditional system. The formula-based fund flow system will be based on some basic parameters to determine the scale of the grant. Financial Administration Division might go further to boost campuses in receiving package support who want to go for the status of autonomous institutions. The expenses in transition must be met by the support from UGC.

\section{Planning, Expenditures and Expected Results}

Universities of Nepal receive financial support from the Government of Nepal (GoN) through the Ministry of Education and it is channelized via the University Grants Commission (UGC). It associates the financial resources both from the GoN and international development partners. However, the medical academies receive financial support for higher education and research directly from the Ministry of Health and Population. The grant every university receives depends on the size of the university, more specifically the number of students, faculties, nature of research, required physical facilities, among others. University Grants Commission annual report provides annual expenditures, number of student enrolments, teachers, the student-teacher ratio, and research support expenses per student and teacher. However, it lacks systematic release of the data in successive years.

Currently, the online report exists for the year 2007/08, 2010/11, and 2017/18 only. Consequently, the systematic analysis of the major indicators has become cumbersome and sometimes likely to be misleading. Available statistic from the year 2001/02 onward shows the growth rate of an annual budget to higher education fluctuating significantly. It fluctuated widely within the range of -12 percent to approximately +34 percent during 2001/02-2011/12 despite monotonic growth of the number of students and teachers in the universities for several years (Section 1.2). Should the figures are converted into a constant price with reference to a base year; the fluctuations would be further wider. However, in nominal terms, the overall grants are growing from 2003/04. At the current price level, the annual grants to all universities have 
reached Rs. 9310, millions for the year 2017/18. The current five-year plan (2015-2020) is unavailable to individuals and researchers; therefore, an assessment of the success of the current plan that is under operation is yet to be conducted.

Expenses and Funding Sources: UGC has been providing research funds to universities, campuses and the faculty members as a part of the Higher Education Reform Project (HERP). Research funds are categorized as Ph. D. and M.Phil. fellowship, small research development and innovation grants, thesis preparation support for persons with disabilities, travel grants for participating in international conferences, support for conducting capacity development programs/training/seminars, partial support for Ph. D. fellows, Master's and M. Phil. thesis preparation support and faculty research grants. The government of Nepal has allocated 1.29 percent of the total budget for research and development in different sectors for the fiscal year 2076/77 $(2019 / 20)$. The major breakdown of this budget was as follows:

- General research and development service for the federal government: Rs 198,810,000

- Research and development in Economic affairs: Rs. 2,043,000,000 for federal and Rs. 3,500,000 for province

- Research and development for environment protection: Rs. 3,974,000,000

- Research and development for health: Rs. 11,039,800,000

- Research and development for culture and religion: Rs. 62,200,000

- Research and development for education: Rs. 17,300,000

- Research and development for social protection: Rs. 773,700,000

For education, science and technology, the budget increased to Rs.163.76 billion. Total budget of UGC for the coming five years has been projected to be US $\$ 1$ 1,100 million. This consists of contributions by the government (93\%) and the grants from the International Development Association (IDA) of the World Bank (7\%), (UGC, 2019). However, the expenditures will follow two-pronged strategies: Results-Based Financing for Reforms and Expenditure Based Financing for Program Management. Results-Based Financing for Reforms refers to expenditure based on the actual expenditures that occurred in achieving given outputs. Therefore, every single Rupee spent under reform is associated with particular output. On the other side, Expenditure Based Financing for Program refers to the financing to every component of the program based on the size of the availability of the total budget. A summary of the proposed expenses and funding sources are as follows:

Support National Program

Total Financing size (5 years) : : US\$1,100 mil

Government

: US\$ $1,020 \mathrm{mil}$

Proposed IDA Contribution : US\$ 80 mil

Funding Modality

Implementing Agency

: Results-Based Financing for Reforms

: Expenditure Based Financing for Program Management

GON-WB Project Signing (Expected) : November 2020

Scenarios and Projections: This section makes a summary of the sustainability plan of UGC in Nepal in the past years which will make a background to set the realistic targets in the next phase (2020-2025) of the sustainability plan that will be discussed in the next section.

Teaching: The general trend and existing scenarios of the higher education in Nepal can be summarized with reference to some indicators. Education Information Management System (EMIS) reports are either not published annually or not annually made available to the public. More importantly, the measurable and available indicators are enrolment in higher education, the number of post-graduate (masters, PGD, MPhil, and Ph.D.) students, numbers of teachers, student-teacher ratio, total grants, and net public expenditure per student. The trends of these indicators over the years are as presented in Table 9.

\footnotetext{
${ }^{1}$ U US\$ $\approx 116$ (January 2021).
} 
Table 9: Existing Trend in Nepal's Higher Education

\begin{tabular}{lll}
\hline Indicators & $\mathbf{2 0 1 0} / \mathbf{1 1}$ & $\mathbf{2 0 1 7} / \mathbf{1 8}$ \\
\hline Enrolment in higher education & 407934 & 423996 \\
Masters, PGD, MPhil, Ph.D. students & 76166 & 59267 \\
Number of teachers & 15365 & 9269 \\
Student-teacher ratio & 26 & 14.14 \\
Total grants & & 9.31 billion \\
Net public expenditure per student (in Rs.) & 12481.6 & NA \\
\hline
\end{tabular}

Source: Author's compilation from different sources including (The British Council, 2019).

Table 9 shows the discouraging trend of major indicators in Nepal's higher education. Students' enrolment in higher education has grown just by 3.94 percent during seven years (2010/11-2017/18), 0.56 percent per year. More specifically, even this dismal growth is concentrated in undergraduate enrolment; the enrolment in Masters, MPhil, Post-Graduate Diploma, and Ph.D. has rather declined by 22 percent in seven years, more than three percent annually.

Research and Publications: Despite the deterioration in teaching components, research and publication endeavors are rather improving in Nepal with grants from UGC. The number of M.Phil \& Ph.D. grants are increasing over the years. Furthermore, the number of research articles published in peer-reviewed journals is also increasing in successive years. UGC provides three different research awards: small mini research grants to individual faculty members, faculty research, and collaborative research. The total awards granted in the last four years far exceed the target (Figure 3).

Figure 3: Research Projects Awarded

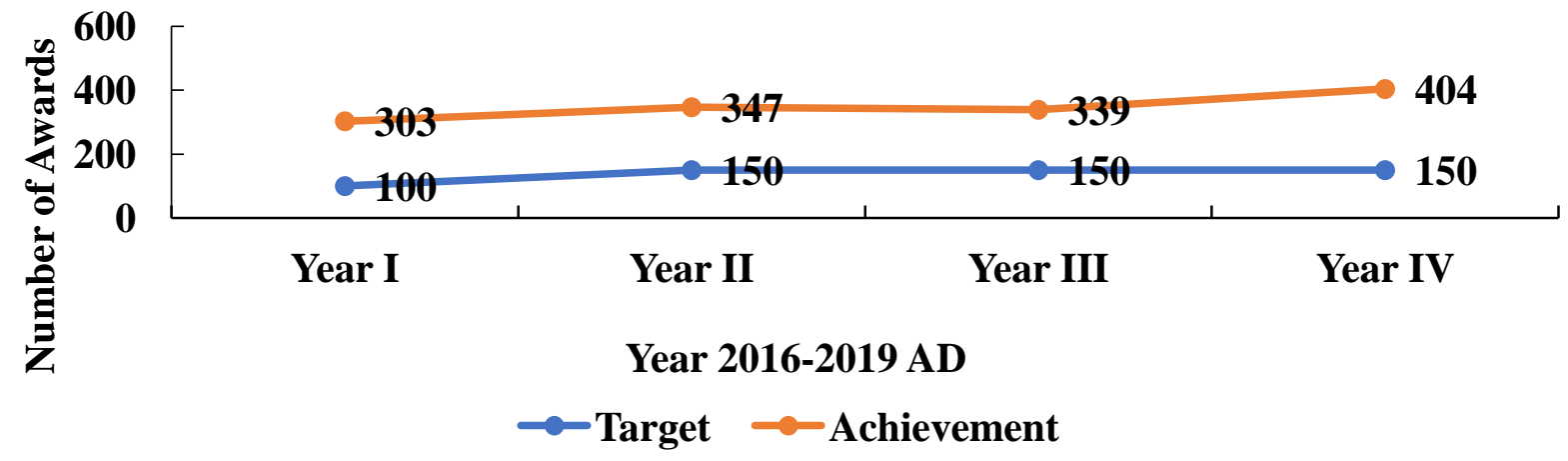

Data Source: Research Division, UGC, 2019.

The rise in the number of research awards in successive years has a corresponding impact on the number of scientific publications (Figure 4).

Figure 4: Number of Publications by Award Recipients

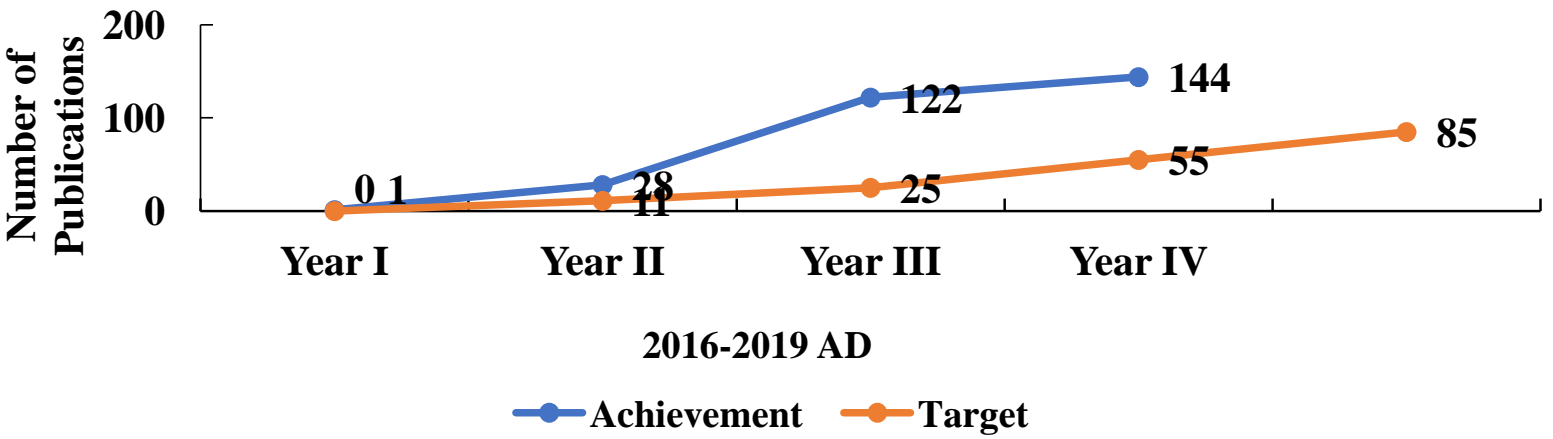

Data Source: UGC, Research Division. 
Note: The figure for 2019 refers up to July only. The existing trend shows that achievements for the year 2020 will also be higher than the target. The figures for 2020 are yet to come.

Milestones and Timeline: It is suggested to make Nepal's higher education in standards of the South Asian average by the end of the second phase of the Higher Education Reform Project (HERP), i.e. by 2025. Three major milestones to be achieved within this timeline are proposed as follows (Table 10):

Table 10: Milestones Proposed for 2025

\begin{tabular}{lll}
\hline Indicators & Currently & Proposed level by 2025 \\
\hline $\begin{array}{l}\text { Public sector spending on higher education (\% of GDP } \\
\text { per capita) }\end{array}$ & 40.4 & 5 \\
$\begin{array}{l}\text { No. of universities in Nepal within top } 1000 \\
\text { universities in the world }\end{array}$ & 1 & $1.0^{+}$ \\
$\begin{array}{l}\text { Cost of 1GB of mobile data to every student in Nepal } \\
\text { universities (in US\$) }\end{array}$ & &
\end{tabular}

Data Sources: Current figures from The World Bank, UNESCO Institute for Statistic, Times Higher Education, and UNESCO. Proposed figures are the author's estimation based on South Asian standards.

Note: + South Asian standard. The improvements in the higher education system in Nepal should be gauzed with reference to these basic milestone indicators.

\section{Findings and Strategic Recommendations}

Findings: Nepal's higher education faces several problems. More importantly, there remains poor alignment of higher education with labor market needs. "Quality Assurance" and "Quality Enhancement" in higher education with reference to the need of the labor market deem necessary in this regard. The declining number of students and faculty members in Nepal universities is the major challenge now. Although the number of undergraduate students is marginally growing over the years, the problem is more severe in postgraduate education. As of May 2019, over 300,000 Nepali students are studying abroad in various universities; their concentration is more in Australian, and Japanese universities followed by Chinese, US, Indian, and European universities. Moreover, according to the Foreign Education Department in the Ministry of Education, the number of Nepalese students who have received permission of going abroad for higher education has reached 323,972 by May 1999 (NepaliSansar, Online Media, 2019). The number of emigrant Nepali students, when compared with the number of students enrolled in Nepal universities, shows that over 41 percent of Nepali students are studying abroad and less than 59 percent in Nepal universities. When the number of students who have received permission to study abroad is also considered as abroad students, the former significantly exceeds the number of students in Nepal universities and; the ratio becomes 60:40. The number of Nepali students going abroad in private fund got momentum from the year 2011/12. That year witnessed 10,354 students going abroad and the figure reached 56,216 in the year 2017/18.

In current years the number of students going abroad for higher education has increased annually by approximately 10,000. This alarming trend has not only caused erosion of the number of students from Nepal universities but has also caused a significant outflow of foreign exchange of the country. During the last six years over NPR 600 billion have flown out from the country (more than one-fifth of its current GDP), NPR 40 billion in the fiscal year 2018/19 alone (NayaPatrika and Nepali Times, 23 July 2019). Governance and regulatory framework is rather a week in Nepalese higher education. University's highest authority gets an appointment with political affiliation. It is quite common in Nepalese public universities. This tendency, thereafter, moves downward for the appointment of deans, department heads, and the heads of various divisions in the universities. Furthermore, student organizations are quite strong in affiliated campuses of public universities; they are the sister organizations of respective political parties. This makes group meetings and mass gatherings quite frequent with lots of disturbances in running the lectures. Moreover, classes are more of lecture types and fewer workshops are organized. Research and innovation are rather weak in Nepal universities. Teachers with long years of services despite the lack of research and innovation 
have a high chance of getting promotion compared to faculty members with strong research, innovation, and publication performance during a short span of time. The promotional activities are, therefore, more hierarchical rather than based on academic merits and excellence.

Strategic Recommendations: Higher education reform in Nepal requires several strategic measures. Reforms are warranted in four major fronts: teaching, research, institutional, and fund flow system. This section enumerates some of them.

- The sustainability plan provides due emphasis to market relevance and quality of education with its assessment. The mismatch between the market requirements and the quality/skills of the graduates needs to be mitigated gradually.

- Academic and scientific papers published in peer-reviewed international journals should be the major criteria of the recruitments and promotion of the faculty members. Fast track promotion and recruitment system should be strictly implemented in every department/faculties based on the international standard/norms fulfilled by the faculty members. More specifically, this should be a professor's and associate professor's level. The recruited faculty members should be provided with the responsibilities of winning competitive grants at least once in every academic year followed by a scientific publication. This will help upgrade the universities in global university ranking.

- Excellence-based faculty recruitment should get emphasis. So far, the recruitment of the faculty members gives undue importance to the longevity of the services they have rendered to the universities. Emphasis should be on the academic merit-based recruitment system. It is recommended to dissolve the Service Commission in the universities whose works can be more politically-biased as history shows. Faculty recruitment should be by the department or graduate school itself. A committee of senior professors including some foreign university professors would review the publications, make the evaluation, and make a recommendation for the recruitment/promotion. In the case of the administrative staff, the Human Resource division of the respective university can follow the university-specific system in collaboration with the Public Service Commission of the country.

- Age limit to the promotion or recruitment of the faculty member should be completely removed so long as $\mathrm{s} / \mathrm{he}$ is below the retirement age.

- The courses in every academic program require revision regularly based on their market relevance, the scope for employability, and required skills in the market. It will boost institutional quality enhancement activities.

- The age barriers in the entry and promotion of faculty members should be completely removed so long as $\mathrm{s} / \mathrm{he}$ is below the retirement age. The evaluations should be completely based on academic merits rather than the age and longevity of the services. The involvement of foreign university professors should be an integral part of the evaluation/recruitment process. It will gradually scale-up the academic excellence of the university to international standards.

- Subsidies are warranted to provide mobile data to the students/researchers in the universities and their constituents as well as affiliated campuses. This will substantially reduce the cost of education materials to the students on one hand and students will have recent educational products on the other.

- The research award schemes established by UGC in the form of three different grants have proved to be very effective. It has a significant positive impact on publications in refereed journals. The schemes are recommended to continue in the proposed model as well.

- Data management and information system require strengthened. Universities will develop their network servers to connect their entire constituent, private, and community campuses. 


\section{References}

The British Council. (2019). Digital globalization of knowledge and the impact on higher education in South Asia and Europe, The British Council, London.

Ceulemans, K., Lozano, R. \& Alonso-Almeida, M. D. M. (2015). Sustainability reporting in higher education: interconnecting the reporting process and organizational change management for sustainability, Sustainability, MDPI, Open Access Journal, 7(7), 1-23.

Lidstone, L., Wright, T. \& Sherren, K. (2015). Canadian STARS-rated campus sustainability plans: priorities, plan creation and design, Sustainability, MDPI Open Access Journal, 7(1), 1-22.

MOE (Ministry of Education). (2012). Report by the task force formed by the Ministry of Education for the human resources in UGC, MOE, Kathmandu.

NepaliSansar. (2019). Online Media, Nepal Foreign Education Department: As many as 323,972 Students Studying Abroad, wired at: https://www.nepalisansar.com/education/nepal-foreign-educationdepartment-as-many-as-323972-students-studying-abroad/

Toutkoushian, R. K. \& Paulsen, M. B. (2016). Economics of Higher Education: Background, Concepts, and Applications, Springer.

UGC (University Grants Commission). (2017). Education Management Information System (EMIS) Report 2017/18, UGC, Sanothimi, Bhaktapur.

UGC (University Grants Commission). (2012). Education Management Information System (EMIS) Report 2010/11, UGC, Sanothimi, Bhaktapur.

UGC. (2019). Nurturing excellence in higher education reform project, presentation slides, Sanothimi, Bhaktapur.

World Bank. (2007). Higher Education Country Summary: Nepal World Bank, Kathmandu. 